\title{
Smoking Characteristics on Junior High School Students: A Cross-Sectional Study
}

\author{
Muhammad Rachmat ${ }^{1}$, Nur Arifah ${ }^{2 *}$, Tanti Asrianti ${ }^{3}$, Andi Tenri Awaru ${ }^{4}$, Muliati Hidayat ${ }^{1}$, Masriadi Masriadi $^{5}$, Sitti Andriani Anwar ${ }^{6}$ \\ ${ }^{1}$ Department of Health Promotion and Behavior, Faculty of Public Health, Hasanuddin University, Makassar, Indonesia; \\ ${ }^{2}$ Department of Hospital Management, Faculty of Public Health, Hasanuddin University, Makassar, Indonesia; ${ }^{3}$ Department of \\ Epidemiology, Faculty of Public Health, Mulawarman University, Samarinda, Indonesia; ${ }^{4}$ Nusantara Sehat Penugasan Individu \\ Batch 1, Ministry of Health Republic of Indonesia; ${ }^{5}$ Puskesmas Liu, Kabupaten Wajo, Sulawesi Selatan, Indonesia; ${ }^{6}$ Department \\ of Epidemiology, Faculty of Public Health, Hasanuddin University, Makassar, Indonesia
}

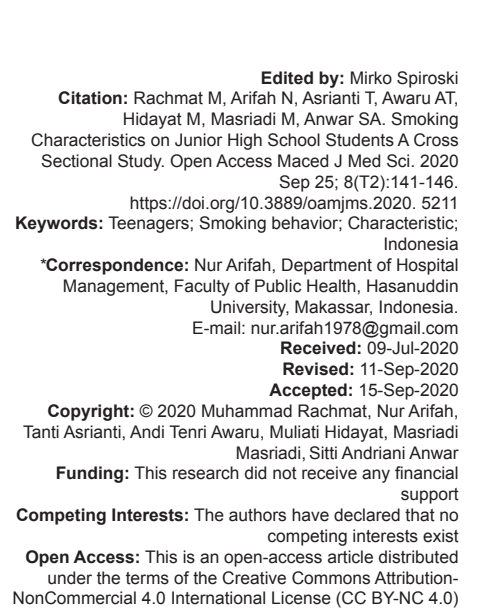

\section{Abstract}

BACKGROUNG: The age of new smokers has shifted to a younger age group. Smoking has become a trend among teenagers.

AIM: The purpose of this study was to obtain a description of the characteristics of junior high school teenagers with smoking habit.

METHODS: This research was a survey with cross-sectional observational study design. Respondents were male and female students in two public Junior High Schools in Makassar City, Indonesia. 1062 students were chosen, 473 were male students and 589 were female students. Data were collected using structured questionnaires. Univariate analysis was conducted to see the characteristics of respondents.

RESULTS: The results showed $18.4 \%$ respondents never smoked with details of $39.4 \%$ male students and $1.5 \%$ female students. Students who ever smoked, as many as $26.7 \%$ are still smoking until currently with details of $28 \%$ male students and $1.5 \%$ female. As many as $11.3 \%$ of students had low knowledge about smoking, $27.8 \%$ interacted with peers who smokes, $17.3 \%$ lived with parents who smokes, and $18.8 \%$ interacted with tobacco advertising.

CONCLUSIONS: Teen smokers have the potential to become long-term smokers. The high number of teenage smokers will worsen the public health situation. Therefore, health promotion for prevention and intervention of smoking behavior in schools needs to be done intensively.

\section{Introduction}

The use of Tobacco can effect the cause of preventable death according to the Department of Health and Human Service US [1]. The World Health Organization and Oxford University imply that every secondary smoker would die prematurely due to smoking [2].

Every year, more than 217,000 people die in Indonesia due to diseases caused by cigarettes [3]. Smoking behavior has spread to almost all age groups and has now become a trend in teenage age groups. Smoking was considered could lower the stress, anxiety, and depression [4].

Results of Riskesdas (Basic Health Research) in 2013 shown that as many as $1.4 \%$ of smokers in Indonesia are at the age of 10-14 years. By habit, $0.5 \%$ teenagers are smoking every day and $0.9 \%$ of them are smoking occasionally [5].

Teenagers are a vulnerable age group and have the potential to become long-term smokers. Longterm smokers are at risk of facing up to 3 times higher deaths than nonsmokers [6]. Smoking behavior, not only as a risky behavior, but it can also be a bridge for teenagers to start trying alcoholic beverages, narcotics, psychotropic, and other addictive substances.

Personal, socio-cultural, and environmental are some factors for young people to smoke [7], [8]. The supportive numbers of father and child conversations, maternal smoking, and spending time with peers are significantly related with smoking risk experimentation on early teenagers [9].

However, teenagers tend to break away from parents and spend time interacting with their peers [10]. A study of 178 elementary school students in Bandar Lampung shows that there is a relationship of peer's role to smoking behavior. More than $50 \%$ of students have bad peers, and as many as 64 of them, have smoked. There are only five students who have good peers, yet have smoked [11].

Research on the description of smoking behavior in teenagers in Bantul District conducted to 188 junior high school students stated that respondents who started smoking at the age of 11,12 , and 13 mostly 
came from families with smoking father and male brother [12]. Another study of 471 junior high school students from 13 junior high schools in Makassar showed that there was a relationship between peer group, family, cigarette advertisement, and attitudes toward teens smoking behavior [13].

\section{Materials and Methods}

\section{Data and subjects}

This study is a preliminary study (baseline) for the study of intervention in junior high school students. The research data were collected in two public junior high schools in Makassar City, South Sulawesi, Indonesia. This research was an observational study with survey method. The number of samples was 1062 people who were students in the $7^{\text {th }}$ and $8^{\text {th }}$ grades of junior high school. Primary data were obtained through a structured questionnaire list that was distributed to all male and female students present at the time of data collection.

\section{Measurement}

To investigate smoking characteristic, a standardized interview questionnaire was used. The questionnaire used has been tested on its validity and reliability in the same population in different public schools. The smoking characteristic was include history of smoking, sex, grades, level of knowledge, smoking behavior based on family environments, and interaction with peers. Data collection was done after obtaining permission from the school principal. Respondents signed the informed consent after receiving explanation about the research. Respondents were arranged in such a way that the information obtained reflects the true state of the student. Data analysis was done descriptively to know the frequency distribution of variables studied.

\section{Statistical analysis}

To determine the differences knowledge and attitudes based on grades and sex, Chi-square test was used for this analysis. Statistical analyses were conducted with SPSS version 20.0 and $p<0.05$ indicated statistical significance.

\section{Results}

\section{Characteristics of respondents}

Respondents consisted of 473 male students and 589 female students, with age ranging from of 11 to
16 years old. Respondents characteristic are presented in Table 1.

Table 1: Characteristics of respondents

\begin{tabular}{lll}
\hline Characteristics of respondents & Total (n) & Percentage \\
\hline Origin of school & & \\
$\quad$ SMPN 37 Galangan Kapal & 445 & 41.9 \\
$\quad$ SMPN 25 Sudiang & 617 & 58.1 \\
Grade & 549 & 51.7 \\
$\quad 7^{\text {th }}$ grade & 513 & 48.3 \\
$\quad 8^{\text {th }}$ grade & & \\
Sex & 473 & 44.5 \\
$\quad$ Male & 589 & 55.5 \\
$\quad$ Female & 53 & 5.0 \\
Level of knowledge & 490 & 46.1 \\
$\quad$ Low & 519 & 48.9 \\
$\quad$ Average & & \\
$\quad$ High & 195 & 18.4 \\
History of Smoking & 867 & 81.6 \\
$\quad$ Have smoked & & \\
$\quad$ Have never smoked &
\end{tabular}

\section{Smoking history}

The distribution of smoking history of respondents by sex is clearly shown in Table 2 . Of the total respondents, $18.4 \%$ of the respondents claimed to have smoked, with nine people of them $(1.5 \%)$ are female, and 186 of them (39.4\%) are male.

Table 2: Distribution of respondents' smoking history by sex

\begin{tabular}{|c|c|c|c|c|c|c|}
\hline \multirow[t]{3}{*}{ Sex } & \multicolumn{4}{|c|}{ History of smoking } & \multirow{2}{*}{\multicolumn{2}{|c|}{ Total }} \\
\hline & \multicolumn{2}{|c|}{ Have smoked } & \multicolumn{2}{|c|}{ Have never smoked } & & \\
\hline & $\mathrm{n}$ & $\%$ & $\mathrm{n}$ & $\%$ & $n$ & $\%$ \\
\hline Male & 186 & 39.3 & 287 & 60.7 & 473 & 100 \\
\hline Female & 9 & 1.5 & 580 & 98.5 & 589 & 100 \\
\hline Total & 195 & 18.4 & 867 & 81.6 & 1062 & 100 \\
\hline
\end{tabular}

The distribution of respondents' smoking history based on the level of knowledge is clearly illustrated in Table 3. There were $19.3 \%$ of respondents who had smoked and had moderate knowledge level and $18.3 \%$ had high knowledge.

Table 3: Description of smoking history based on knowledge level

\begin{tabular}{|c|c|c|c|c|c|c|}
\hline \multirow[t]{3}{*}{ Level of knowledge } & \multicolumn{4}{|c|}{ History of smoking } & \multirow{2}{*}{\multicolumn{2}{|c|}{ Total }} \\
\hline & \multicolumn{2}{|c|}{ Have smoked } & \multicolumn{2}{|c|}{ Have never smoked } & & \\
\hline & $\mathrm{n}$ & $\%$ & $\mathrm{n}$ & $\%$ & $\mathrm{n}$ & $\%$ \\
\hline Low & 6 & 11.3 & 47 & 88.7 & 53 & 100 \\
\hline Average & 94 & 19.3 & 394 & 80.7 & 488 & 100 \\
\hline High & 95 & 18.3 & 423 & 81.7 & 518 & 100 \\
\hline Total & 195 & 18.4 & 864 & 81.6 & 1059 & 100 \\
\hline
\end{tabular}

\section{Smoking behavior}

Of the $18.4 \%$ of respondents who ever smoked, there are $26.7 \%$ of them who are still smoking and all are male respondents. The distribution of respondents based on smoking behavior is presented in Table 4.

Description of respondents' smoking behavior based on the level of knowledge is presented in Table 4. The majority of respondents who are still smoking have low knowledge about cigarettes (33.3\%).

The description of respondents' smoking behavior based on interactions in the family environment is presented in Table 5. Respondents who smoke more and lived in the same household with smoking relatives $(28.2 \%)$ are more frequent than those who do not have relatives that smoke. In addition, respondents who 
Table 4: Distribution of respondents based on smoking behavior

\begin{tabular}{|c|c|c|c|c|c|c|}
\hline \multirow[t]{3}{*}{ Sex } & \multicolumn{4}{|c|}{ Smoking behavior } & \multirow{2}{*}{\multicolumn{2}{|c|}{ Total }} \\
\hline & \multicolumn{2}{|c|}{ Yes } & \multicolumn{2}{|l|}{ No } & & \\
\hline & $\mathrm{n}$ & $\%$ & $\mathrm{n}$ & $\%$ & $\mathrm{n}$ & $\%$ \\
\hline Male & 52 & 28.0 & 134 & 72.0 & 186 & 100 \\
\hline Female & 0 & 0.0 & 9 & 100.0 & 9 & 100 \\
\hline Total & 52 & 26.7 & 143 & 73.3 & 195 & 100 \\
\hline
\end{tabular}

smoke more often find their families smoking $(27.5 \%)$ and often find cigarettes at home (28.3\%).

Table 5: Distribution of respondents' smoking behavior based on knowledge level

\begin{tabular}{|c|c|c|c|c|c|c|}
\hline \multirow[t]{3}{*}{ Level of knowledge } & \multicolumn{4}{|c|}{ Smoking behavior } & \multirow{2}{*}{\multicolumn{2}{|c|}{ Total }} \\
\hline & \multicolumn{2}{|c|}{ Yes } & \multicolumn{2}{|l|}{ No } & & \\
\hline & $\mathrm{n}$ & $\%$ & $\mathrm{n}$ & $\%$ & $\mathrm{n}$ & $\%$ \\
\hline Low & 2 & 33.3 & 4 & 66.7 & 6 & 100 \\
\hline Average & 27 & 28.7 & 67 & 71.3 & 94 & 100 \\
\hline High & 23 & 24.2 & 72 & 75.8 & 95 & 100 \\
\hline Total & 52 & 26.7 & 143 & 73.3 & 195 & 100 \\
\hline
\end{tabular}

Distribution of respondents' smoking behavior based on interaction with peers is presented in Table 6 . The majority of respondents who smoke have close friends that smoke $(30.7 \%)$ compared to those who do not have close friends that smoke. In addition, respondents who smoke admitted that they are often invited by friends to smoke $(35.2 \%)$ and often given cigarettes by their friends (35.0\%). More smoking respondents claimed to have been forced by friends to smoke $(27.8 \%)$ than those who have never smoked.

Table 6: Distribution of respondents' smoking behavior based on interaction within the family environment

\begin{tabular}{|c|c|c|c|c|c|c|}
\hline \multirow{3}{*}{$\begin{array}{l}\text { Interactions in the family } \\
\text { environment }\end{array}$} & \multicolumn{4}{|c|}{ Smoking behavior } & \multirow{2}{*}{\multicolumn{2}{|c|}{ Total }} \\
\hline & \multicolumn{2}{|c|}{ Yes } & \multicolumn{2}{|l|}{ No } & & \\
\hline & $\mathrm{n}$ & $\%$ & $\mathrm{n}$ & $\%$ & $\mathrm{n}$ & $\%$ \\
\hline \multicolumn{7}{|c|}{ Live in the same house with relatives that smokes } \\
\hline Yes & 29 & 28.2 & 74 & 71.8 & 103 & 100 \\
\hline No & 23 & 25.0 & 69 & 75.0 & 92 & 100 \\
\hline \multicolumn{7}{|l|}{ Often find relatives smoking } \\
\hline Yes & 30 & 27.5 & 79 & 72.5 & 109 & 100 \\
\hline No & 22 & 25.6 & 64 & 74.4 & 86 & 100 \\
\hline \multicolumn{7}{|c|}{ Often find cigarettes at home } \\
\hline Yes & 32 & 28.3 & 81 & 71.7 & 113 & 100 \\
\hline No & 20 & 24.4 & 62 & 75.6 & 82 & 100 \\
\hline Total & 52 & 26.7 & 143 & 73.3 & 195 & 100 \\
\hline
\end{tabular}

Distribution of respondents' smoking behavior based on interaction with cigarette advertisement is presented in Table 7. Respondents who smoke more often paid attention to cigarette advertisement (28.3\%) compared to those who did not pay attention to cigarette advertisement. Respondents who smoke also claimed to be more interested in images shown in cigarette advertisements $(44.0 \%)$ and are moved to try smoking like how it is shown in ads (75.0\%). In addition,

Table 7: Distribution of respondents' smoking behavior based on interaction with peers

\begin{tabular}{|c|c|c|c|c|c|c|}
\hline \multirow[t]{3}{*}{ Interactions with peers } & \multicolumn{4}{|c|}{ Smoking behavior } & \multicolumn{2}{|c|}{ Total } \\
\hline & \multicolumn{2}{|c|}{ Yes } & \multicolumn{2}{|l|}{ No } & & \\
\hline & $\mathrm{n}$ & $\%$ & $\mathrm{n}$ & $\%$ & $\mathrm{n}$ & $\%$ \\
\hline \multicolumn{7}{|c|}{ Have close friends that smoke } \\
\hline Yes & 50 & 30.7 & 113 & 69.3 & 163 & 100 \\
\hline No & 2 & 5.2 & 30 & 93.8 & 32 & 100 \\
\hline \multicolumn{7}{|c|}{ Invited by friends to smoke } \\
\hline Have & 43 & 35.2 & 79 & 64.8 & 122 & 100 \\
\hline Never have & 9 & 12.3 & 64 & 87.7 & 73 & 100 \\
\hline \multicolumn{7}{|c|}{ Given a cigarette by friends } \\
\hline Have & 36 & 35.0 & 67 & 65.0 & 103 & 100 \\
\hline Never have & 16 & 17.4 & 76 & 82.6 & 92 & 100 \\
\hline \multicolumn{7}{|c|}{ Forced by friends to smoke } \\
\hline Have & 10 & 27.8 & 26 & 72.2 & 36 & 100 \\
\hline Never have & 42 & 26.4 & 117 & 73.6 & 159 & 100 \\
\hline Total & 52 & 26.7 & 143 & 73.3 & 195 & 100 \\
\hline
\end{tabular}

Table 8: Distribution of respondents' smoking behavior based on interaction with cigarette advertisements

\begin{tabular}{|c|c|c|c|c|c|c|}
\hline \multirow{3}{*}{$\begin{array}{l}\text { Interaction with cigarette } \\
\text { advertisements }\end{array}$} & \multicolumn{4}{|c|}{ Smoking behavior } & \multirow{2}{*}{\multicolumn{2}{|c|}{ Total }} \\
\hline & \multicolumn{2}{|c|}{ Yes } & \multicolumn{2}{|l|}{ No } & & \\
\hline & $\mathrm{n}$ & $\%$ & $\mathrm{n}$ & $\%$ & $\mathrm{n}$ & $\%$ \\
\hline \multicolumn{7}{|c|}{ Paid attention to cigarette ads } \\
\hline Yes & 28 & 28.3 & 71 & 71.7 & 99 & 100 \\
\hline No & 24 & 25.0 & 72 & 75.0 & 96 & 100 \\
\hline \multicolumn{7}{|c|}{ Interested with images shown in cigarette ads } \\
\hline Yes & 11 & 44.0 & 14 & 56.0 & 25 & 100 \\
\hline No & 41 & 24.1 & 129 & 75.9 & 170 & 100 \\
\hline \multicolumn{7}{|c|}{ Interested with messages in cigarette ads } \\
\hline Yes & 16 & 25.0 & 48 & 75.0 & 64 & 100 \\
\hline No & 36 & 27.5 & 95 & 72.5 & 131 & 100 \\
\hline \multicolumn{7}{|c|}{ Moved to try smoking like how it is shown in cigarette ads } \\
\hline Yes & 21 & 75.0 & 7 & 25.0 & 28 & 100 \\
\hline No & 31 & 18.6 & 136 & 81.4 & 167 & 100 \\
\hline Total & 52 & 26.7 & 143 & 73.3 & 195 & 100 \\
\hline
\end{tabular}

the respondents who smoke more did not pay attention to the message in cigarette advertisement $(27.5 \%)$ compared to those who pay attention to the message on cigarette advertisement (Table 8).

\section{Bivariate analysis of knowledge and}

\section{attitude}

Difference in respondents' knowledge and attitude based on grade and gender is presented in Table 9. The average score of knowledge in $7^{\text {th }}$ grade is 13.29 and $8^{\text {th }}$ grade is 13.50 , the statistical test obtained $p(0.228)>0.05$, which means there is no difference in the average knowledge score between $7^{\text {th }}$ grade and $8^{\text {th }}$ grade. While the average attitude score in $7^{\text {th }}$ grade is 91.84 and $8^{\text {th }}$ grade is 94.42 , the statistical test obtained $p(0.002)<0.05$, which means that there is a differences in the average attitude score between $7^{\text {th }}$ grade and $8^{\text {th }}$ grade.

Table 9: Differences in respondents knowledge and attitudes based on grade and gender

\begin{tabular}{|c|c|c|c|c|c|c|}
\hline \multirow{2}{*}{$\begin{array}{l}\text { Characteristics of } \\
\text { respondents }\end{array}$} & \multicolumn{3}{|c|}{ Knowledge } & \multicolumn{3}{|c|}{ Attitude } \\
\hline & Mean & SD & $\mathrm{p}$-value & Mean & SD & $\mathrm{p}$-value \\
\hline \multicolumn{7}{|l|}{ Grade } \\
\hline $7^{\text {th }}$ grade & 13.29 & 2.41 & 0.228 & 91.84 & 12.09 & 0.002 \\
\hline $\begin{array}{l}8^{\text {th }} \text { grade } \\
\text { Sex }\end{array}$ & 13.50 & 2.47 & & 94.42 & 10.90 & \\
\hline $\begin{array}{l}\text { Sex } \\
\text { Male }\end{array}$ & \multicolumn{6}{|c|}{ Sex } \\
\hline Female & 13.55 & 2.38 & & 95.78 & 9.89 & \\
\hline
\end{tabular}

Based on the gender category, the average score of knowledge of male respondents is 13.16 and female is 13.55 , the statistical test results obtained $p(0.028)<0.05$ which means that there is a difference in the knowledge score between male and female. While the average attitude score, which male is 89.13 and female is 95.78 , the statistical test results obtained $p(0.000)<0.05$ which means there is a difference in the average attitude score between male and female.

Table 10 shows the bivariate analysis of age associated with knowledge and attitude. Bivariate analysis for age and knowledge obtained $p(0.423)>0.05$ which means there is a relationship between age and knowledge while the relationship between age and attitude obtained $p(0.243)>0.05$ which means there is no relationship between age and attitude. 
Table 10: Bivariate analysis of age associated with knowledge and attitude

\begin{tabular}{lllll}
\hline Variable & Mean & SD & p-value & r-value \\
\hline Correlation between age and knowledge & & & & \\
$\quad$ Age & 13.37 & 0.79 & 0.423 & 0.028 \\
$\quad$ Knowledge & 13.40 & 2.44 & & \\
$\quad \begin{array}{llll}\text { Correlation between age and attitude } \\
\quad \text { Age }\end{array}$ & 13.37 & 0.79 & 0.243 & -0.041 \\
$\quad$ Attitude & 93.13 & 11.58 & & \\
\hline Pearson correlation & & & &
\end{tabular}

\section{Discussion}

Smoking is one of the risk factors of various diseases which effects are felt only after few years later. Smokers who start at a young age will bear a greater risk. The impact is not only on their physical health but also on individual development [14]. Moreover, teenagers are a vulnerable age group and have the potential to become long-term smokers. Smoking at an early age also provides greater opportunities for other deviant behaviors as it can be start to start marijuana and narcotics [15].

The result of this study shows the respondents that claimed to have smoked most of them are male $(39.4 \%)$. It is in line with research in South Korea that from $17.8 \%$ students of $13-15$ years old in Korea had ever smoked cigarettes, $25.1 \%$ are boys and $9.9 \%$ are girls [16].

Based on history of smoking, in this study, there are still $18.3 \%$ of respondents who had high knowledge have smoked in past. Most frequently cited reason for tobacco use is, "smoking is an easy way to approach another person," cause declining the offers of cigarette from others as being unfriendly. Those who have this perception are more likely to be smokers in future [2].

Becoming a regular smoker has been shown to be a process rather than a single event [8]. Knowledge is one of the factors related to smoking behavior. The results of this study indicate that the majority of respondents who are still smoking have low knowledge about cigarettes (33.3\%). The results also fit the theory that those who have knowledge and understand the high dangers of smoking or have more knowledge will have a low smoking behavior, in the sense that the level of dependence on cigarettes is low [17]. This can be the basis for behavioral change attempts, thus a strategy that can be used is to enlarge the cognitive-intellectual information on the subject.

The family is the smallest social unit that provides the primary foundation for child development. The research found that $17.3 \%$ of respondents who smoke live with parents or family members who are also smoke. This finding shown that family influence children behaviors. A study in 2016 addressed that family factors could affect adolescents' decision on smoking [4]. Family is the closest environment for teenagers. The results of this study indicate that the respondents who smoke the majority have family members who smoke and live with relatives who smoke. This result is accordance to a study result which was conducted in Kuwait; respondents in this research stated that one of the reason teenagers started smoking was because they have family members who smoked [4], [18]. Another study to test whether parent-specific interactions were significantly associated with the onset of smoking experimentation in early teen found that the supportive number of conversation between father and child conversations was consistently associated with a declined risk of across all models experimentation. These findings recommend that family could be a major factor in the arranging health related with teenagers' behaviors [9].

Furthermore, this result is also strengthened by a study in 2000; "Children residing with smokers were 3 times as likely to be currently smoking; 4 times as likely to be frequently smoking, 2 times as likely to have friends who smoke; and 4 times as likely to say they started smoking because family members smoked" [18]. It means, the surrounding environment and school participation give nuances to the development of children. Because of this, the good and bad of the family structure and the surrounding community influence the good or bad growth of the child's personality [19].

The development of the child's personality is not only influenced by parents and family but also by the school environment and friends outside the school [11]. The child will begin to withdraw his interaction with the parent's environment to develop new values. The formation of new values is done by the identification, imitation of certain figures, and by developing their own.

In several level of smoking, illustrated as an involving friendship and condiment of social activity in making new friends and develop relationships in easy way. Offering cigarettes between each others means as an interaction of social and a friendly gesture. Meanwhile, the beggar to reach acceptance from peers applying implied pressure and effect also promotes smoking or smoking attack [2].

The results are shown more respondents who smoke had close friends or peers who smoke as well. The results of this study are in line with research conducted in China that having peers who smoked was a dominant independent as contributor to youth smoking. Study conducted by Rozi et al. 2016 in Pakistan also shows that peers and families who smoke affect the increasing number of teenage smokers in Pakistan up to $20 \%$ [20]. This suggests that having a smoking friend turned out to be the most important predictor of teen smoking. According to a study conducted in Indonesia, there is a relationship between peer pressure and smoking behavior among elementary school students [21].

Peers have an influence in giving information about cigarettes verbally and also becoming role models for informants. As teenagers, peer relationships 
become much stronger than the family that teens are more affected by the behavior of their friends. In relationships with peers, the need to be part of a social group is a major goal. Individuals tend to follow everything that is done by peers so that they seem to have the same values and behavior. There is a fear of losing social groups if they do not follow what is trending in the group. Therefore, it is very important to make an effort to change the behavior of teens smoking early by using the nearest environment, that is, peers.

Another factor that became one of the characteristics of teen smoking behavior is cigarette advertising. Cigarette advertising as a promotional medium for cigarettes and various types has the potential to shape teenagers smoking attitudes and behavior [13]. Media impressions showing teen idol figures smoking cigarettes will encourage teens to follow suit [22]. The results showed that respondents who smoke were attracted to cigarette advertisement images and were moved to try smoking like an advertisement. This is in line with research conducted by Kustanti in 2014 that there is a relationship between smoking behavior of respondents $(32.4 \%)$ with the influence of cigarette advertising [23]. Viewing advertisements in mass media and electronics that display an image of smokers as a symbol of virility or glamor makes a person triggered to imitate the behavior in the cigarette advertisement [24]

The result on this study found that there is a difference in knowledge between two genders ( $p=0.028)$, where the average score of females (13.16) has better than males (13.55) but there is no difference in average score of knowledge between $7^{\text {th }}$ grade and $8^{\text {th }}$ grade $(p=0.228)$. While for attitude on smoking behavior in teenagers, there is a difference in attitude between genders and between grades (all $p<0.05)$. This study also found that age is associated with knowledge and attitude (all $p<0.05$ ).

A study in India also found a similar result that there is a difference in knowledge among all genders. However, males had significantly better knowledge compared to females ( $p=0.006$ ) and the knowledge score did not improve with the increasing grades. It is also in line with research in Botswana that found tobacco smoking significantly higher among senior students as opposed to those in junior secondary school levels [25]. Another study found that there is an association between general characteristics and scores on attitudes toward smoking among young military conscripts in Taiwan. The overall attitude toward smoking was significantly associated with age and education level (all $p<0.05$ ). Older subjects had higher scores than younger subjects, and subjects with higher levels of education had higher scores than less educated subjects [26]. In this study, males in younger grade with the low knowledge and low attitude are a vulnerable group and have potential to become longterm smokers.

\section{Conclusions}

Based on finding of this study, we can conclude that interaction within the family, peers, and advertisement could affect teenagers' smoking behavior. The knowledge and attitude between genders, grades, and ages are also influence teenagers smoking behavior. Comprehensive strategy needs to prevent adolescent from taking up these habits in the future.

\section{References}

1. U.S. Department of Health and Human Services. Reducing the Health Consequences of Smoking: A Report of the Surgeon General. Rockville, MD: Centers for Disease Control, Office on Smoking and Health; 1989. https://doi.org/10.1037/ e300842003-001

2. Zhang L, Wang W, Zhao Q, Vartiainen E. Psychosocial predictors of smoking among secondary school students in Henan, China. Health Educ Res. 2000;15(4):415-22. https://doi.org/10.1093/ her/15.4.415

3. Malenica M, Prnjavorac B, Bego T, Dujic T, Semiz S, Skrbo S et al. Effect of cigarette smoking on haematological parameters in healthy population. Med Arch. 2017;71(2):132. https://doi. org/10.5455/medarh.2017.71.132-136

PMid:28790546

4. AlKandari NY. Motivation for smoking in male college students in Kuwait. Int J Health Promot Educ. 2016;54:217-28. https:// doi.org/10.1080/14635240.2016.1157510

5. Ministry of Health of the Republic of Indonesia. Basic Health Research (Riskesdas) 2013. Jakarta: Health Research and Development Agency; 2013.

6. Lindawati, et al. Factors that influence the smoking behavior of junior high school students in the South Jakarta area. J Health Qual. 2012;2(4):189-200.

7. Snow PC, Bruce DD. Cigarette smoking in teenage girls Exploring the role of peer reputations, self-concept and coping. Health Educ Res. 2003;18(4):439-52. https://doi.org/10.1093/ her/cyf029

8. Stead M, Hastings G, Tudor-Smith C. Preventing adolescent smoking : A review of options. Health Educ J. 1996;55:31-54. https://doi.org/10.1177/001789699605500105

9. White J. The contribution of parent-child interactions to smoking experimentation in adolescence: Implications for prevention. Health Educ Res. 2012;27(1):46-56. https://doi.org/10.1093/ her/cyr067

PMid:21885673

10. Wegmann L, Bühler A, Strunk M, Lang P, Nowak D. Smoking cessation with teenagers: The relationship between impulsivity, emotional problems, program retention and effectiveness. Add Behav. 2012;37(4):463-8. https://doi.org/10.1016/j. addbeh.2011.12.008

11. Firdaus, et al. Relationships of peers to the smoking actions of public elementary school students in the Panjang district of Bandar Lampung city. J Med Univ Lampung. 2014;2014:56-61

12. Astuti K. Description of smoking habits in adolescents in Bantul regency. Insight J. 2012;10(1):77-87.

13. Rachmat M, Thaha RM, Syafar M. Perilaku merokok remaja sekolah menengah pertama. Kesmas: National Public Health Journal. 2013; 7(11):502-8. 
14. Mulyani TS. The Dynamics of Smoking Behavior in Adolescents, Master of Psychology Program. Surakarta: Muhammadiyah University; 2015

15. Hublet $A$, Bendtsen $P$, de Looze ME, Fotiou $A$, Donnelly $P$, Vilhjalmsson $\mathrm{R}$, et al. Trends in the co-occurance of tobacco and cannabis use in 15-year-olds from 2002 to 2010 in 28 countries of Europe and North America. Eur J Public Health. 2015;25(2):73-75. https://doi.org/10.1093/eurpub/ckv032 PMid:25805793

16. Choi S, Kim Y, Lee J, Kashiwabara M, Oh K. Tobacco use among students aged 13-15 YEARS in South Korea: The 2013 global youth tobacco survey. J Prev Med Public Health. 2017;50(1):60-5. https://doi.org/10.3961/jpmph.16.079 PMid:28173685

17. Wismanto YB, Sarwo YB. Strategies to Stop Smoking Behavior. Semarang: Unika Soegijapranata Publisher; 2007.

18. Zollinger TW, Saywell RM, Muegge C, Bogda LJ. The impact of household smoking on child tobacco use, attitudes and knowledge. Int J Health Promot Educ. 2005;43(2):45-50.

19. Kartono K. Juvenile Delinquency. Jakarta: Raja Grafindo Persada; 2003.

20. Rozi S, Mahmud S, Lancaster G, Zahid N. Peer pressure and family smoking habits influence smoking uptake in teenage boys attending school: Multilevel modeling of survey data. Open J Epidemiol. 2016;6(3):167-72. https://doi.org/10.4236/ ojepi.2016.63018

21. Subramaniam SV, Istiqomah AN, Fadlyana E. Peer Pressure and Smoking Behavior in Elementary School Students. Althea Med J. 2017;4(1):1-5.

22. Ministry of Health Polytechnic Writer Team. Adolescent Health, Problems and Solutions. Jakarta: Salemba Medika; 2010.

23. Kustanti, Ayuk A. Relationship Between Family Influence, Influence of Friends, and the Effect of Cigarette Advertising on Smoking Behavior in Adolescents at SMPN 1 Slogohimo, Wonogiri. Surakarta: Text, Muhammadiyah University; 2014.

24. Samrotul F, Yoyok F. Factors that influence smoking behavior in male students in male dormitory. Stikes J. 2012;5(1):99-109.

25. Mbongwe B, Tapera R, Phaladze N, Lord A, Zetola NM. Predictors of smoking among primary and secondary school students in Botswana. PLoS One. 2017;12(4):1-11. https://doi. org/10.1371/journal.pone.0175640

26. Lin $\mathrm{Y}, \mathrm{Wu} \mathrm{D}$, Lai $\mathrm{H}$, Shi $\mathrm{Z}$, Chu N. Influence of knowledge and attitudes on smoking habits among young military conscripts in Taiwan. J Chin Med Assoc. 2010;73(8):411-8. https://doi. org/10.1016/s1726-4901(10)70089-7

PMid:20728852 